\title{
Towards space engineering curriculum in Hungary
}

\author{
László Bacsárdi \\ Department of Networked Systems and Services \\ Budapest University of Technology and Economics \\ Budapest, Hungary \\ bacsardi@hit.bme.hu
}

\author{
János Józsa \\ Department of Hydraulic and Water Resources Engineering \\ Budapest University of Technology and Economics \\ Budapest, Hungary \\ jozsa.janos@epito.bme.hu \\ Kálmán Kovács \\ Department of Control Engineering and Information Technology \\ Budapest University of Technology and Economics \\ Budapest, Hungary \\ kovacs.kalman@eit.bme.hu
}

\begin{abstract}
Although Hungarian experts made several contributions in the domain of space research and activities, there is no aerospace engineering or space engineering curriculum in Hungary. After informal and formal discussions started years ago, the Budapest University of Technology and Economics is starting the formal process of establishing the space engineering curriculum in Hungary.
\end{abstract}

Keywords—space engineering; curriculum; Hungarian tertiary education

\section{INTRODUCTION}

In Hungary, it is a strategic goal to spread high-tech RDI (research-development-innovation) activities, and to develop the industrial manufacturing and service sectors capable of applying these. Hungary's full ESA membership was a significant step towards achieving the above strategic goal and offered new possibilities for the Hungarian space industry [1]. The expansion of space industry requires a significant number of well-trained professionals experienced in space technology. We would like to introduce the efforts made by the Budapest University of Technology and Economics (BME) to launch the first Hungarian space engineer training.

BME is the leader in Hungarian technical higher education and there is a long tradition of research-based education at the university. There are several application areas which are influenced by space (different technologies, satellite services, etc.) including environment and agriculture, geodesy, intelligent transport, smart cities and smart industry, telecommunication.

The university supports not only several successful personal careers but ensures remarkable contributions to the build-up of institutional and business entities of Hungarian space research and technology.

At the more than two centuries old BME, several researchers and development engineers pursued their education or work who attained world-class achievements in the area of modern space research. The education of technical and scientific fundamentals of space activity has been a considerable part of the curriculum for decades at various faculties of BME. In the past years, our students and staff members participated in the ESERO program, developed the Masat-1, the first Hungarian cubesat and currently working on the SMOG-1, the first Hungarian picosatellite, as well as participated different ESA's educational programs including REXUS/BEXUS program. The different lessons learned of these projects became educational content for the next generation of students [2]. Currently, there are about 20 courses at 4 faculties in the space domain on undergraduate and graduate level.

Although our students and staff members participate national and international space projects, it is not easy to recognize their achievements from educational point of view since aerospace engineering or space engineering curriculum does not exist in Hungary. Fortunately, several stakeholders and influencers raised the need for such a degree in the past years including the authors of this paper. Informal discussions were initialized by Hungarian Astronautical Society (MANT) in 2016, and BME started to push further by harmonizing its internal space related educational processes. According to the current national plans, establishing space engineering degree will be part the new Hungarian Space Strategy which will be adopted hopefully in this year.

In our paper, we detail the different processes which have been done so far towards establishing the aerospace engineering degree in Hungary.

\section{A UNIVERSITY WITH SPACE HERITAGE}

\section{A. Space researchers from the university}

At the more than two centuries old Budapest University of Technology and Economics, several researchers and development engineers pursued their education or work who attained world-class achievements in the area of modern space 
research. We would like to list a few outstanding personalities from the long list below [3].

Tódor Kármán-known in the world as the father of rocket technology-obtained his mechanical engineering diploma in 1902 and lectured for years at the Royal Joseph University-entitled to issue doctoral degree in engineering-as it was called then.

Zoltán Bay, leader of the 1946 ground-breaking Moon radar experiment, established and headed the Department of Atomic Physics at the University.

Ferenc Pavlics, who received his diploma in mechanical engineering in 1950, became famous for being the development engineer of the first extra-terrestrial vehicle, the Moon rover used in the Apollo program.

Gyula Tófalvi, who in 1958 won the Grand Prize of the Brussels World Fair with his ionospheric research equipment, was among the first to obtain electrical engineering diploma at the University.

Antal Bejczy, developer of the remote-control engineering for the Mars Pathfinder, studied at the Faculty of Electrical Engineering until 1956.

Ákos Detreköi, the internationally renowned expert of geoinformatics and remote sensing, remained with the University from receiving his civil engineering diploma through his entire professional career.

The first Hungarian astronaut Bertalan Farkas has close ties to the University: researchers graduating from or working at BME participated the preparations of several experiments developed by Hungarians on the Salyut-6 space station (1980), and he obtained his diploma in engineering at the Faculty of Transportation Engineering of BME.

The second Hungarian to enter space, Charles Simony, living in the USA, also has connections to BME: his father, Károly Simonyi was an outstanding lecturer of BME Faculty of Electric Engineering and Informatics, and Charles established radio contact with BME during his space flights (2007 and 2009), and later visited the Masat-1 development team at BME.

\section{B. Space is the final frontier}

Several space equipment are related to the BME. Masat-1 is the first Hungarian cubesat, important piece of Hungarian history of science has been designed and manufactured at BME. Masat-1 became the first Hungarian made satellite that was offered the possibility to go up into space, and after the successful launch, this became Hungary's first Earth-orbiting artificial celestial body. It was a $1 \mathrm{U}$ cubesat $\left(10 \mathrm{~cm}^{*} 10 \mathrm{~cm} * 10 \mathrm{~cm}\right)$, launched on February 13, 2012 and successfully operated until January 2015. The SMOG-1 picosatellite with $5 \mathrm{~cm} * 5 \mathrm{~cm} * 5 \mathrm{~cm}$ is planned to be launch in this years. The scientific objective is to measure human electromagnetic pollution (hence the name of the satellite) in the near Earth region. Parallel to satellite developments, the operation and development of automated and remote controlled ground station capable of serving satellite contact is among the tasks.
To name one department among others, space research at the Department of Broadband Infocommunications and Electromagnetic Theory has a history with 40 years that saw equipment developed here entering space in more than 20 space missions.

\section{BME Space Forum}

At the Faculties of BME, numerous Departments and research groups perform space research, implementation and education activities, from theory research through the practical manufacture of diverse devices and services, to undergraduate and graduate level education. Recognizing the lucrative opportunities in harmonizing the work of the numerous individually operating research groups, a few years ago three departments undertaking space activities established the BME Space Forum and offered participation in the Forum's work (joining) for all organizations and research groups of the university.

BME Space Forum operation and management is performed by the Federated Innovation and Knowledge Centre of BME (BME EIT). President of Space Forum is Kálmán Kovács, director of BME EIT; vice president is László Bacsárdi. BME EIT was created at the Faculty of Electrical Engineering and Informatics of BME in 2009 to stimulate the research and development activity and the utilization of the research results at the Faculty and to be able to do the same at the university level [4]. BME EIT operates as a R\&D service center. Its major tasks are research coordination and project management. Since 2010, BME EIT has managed 28 projects in the value of $27 \mathrm{M}$ EURO and employed about 2,200 persons in 5,500 contracts. One of the most significant topics coordinated by BME EIT is the space activity (research, application and education) of BME.

There is a long tradition of research-based education in space science at BME. It supports not only several successful personal careers but ensures remarkable contributions to the build-up of institutional and business entities of Hungarian space research and technology.

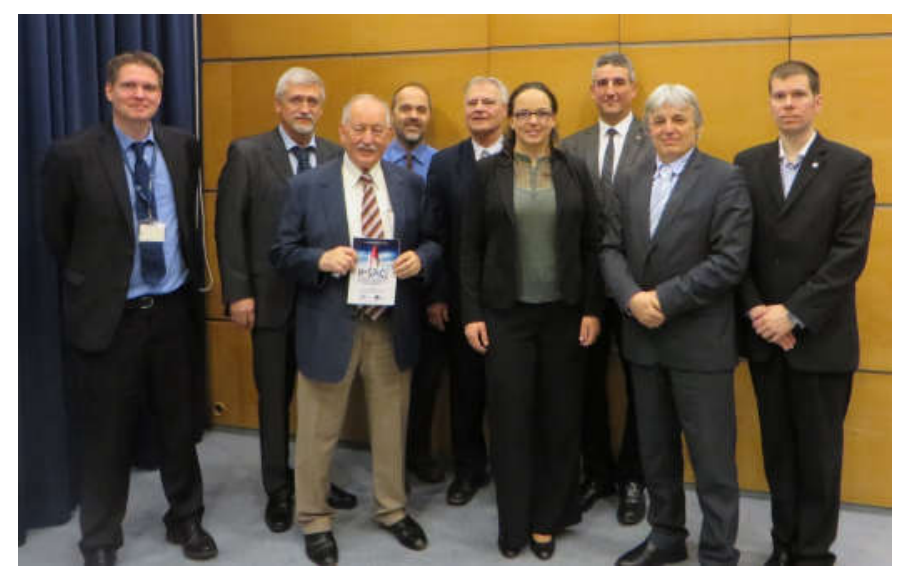

Fig. 1. Before the official opening of H-SPACE 2016 conference, an international conference on research, technology and education of space. From left to right: Richard Jones (Flow Chemistry Society), János Solymosi (BHE Bonn Hungary), Ferenc Darvas (ThalesNano), Tibor Balint (Royal College of Art, now NASA JPL), Rainer Sandau (International Academy of Astrenautics), Fruzsina Tari (Hungarian Space Office), Franco Ongaro (ESA), Kálmán Kovács (BME), László Bacsárdi (BME). 
Currently, 73 Departments of the 8 Faculties encompass the research \& education activities of BME. From among these, 13 Departments of 4 Faculties are members the Space Forum. Participants of Space Forum joined voluntarily. It is their common objective that the various space activities performed at BME should not be dissipated, but all activities in this field should be coordinated along a jointly worked out strategy.

Space Forum represents its member organizations in a uniform manner towards BME's current and future partners, and initiates cooperation that may significantly contribute to the more efficient utilization of the university's research and educational capacities.

\section{ON THE WAY TO THE HUNGARIAN SPACE ENGINEERING CURRICULUM}

In the past years, the different Hungarian stakeholders have agreed in the need of the space oriented tertiary education. Space science and space engineering are in the main focus of the national strategy. As an engineering university, we would like to focus on the space engineering curriculum.

\section{A. H-SPACE conference series}

The H-SPACE conference series refers to our series of "International Conference on Research, Technology and Education of Space" [5-10]. The event is organized by BME EIT - in cooperation with the Hungarian Astronautical Society (MANT). The organization of the conference series started in 2015, at a time of growing opportunities arising from ESA recently granting membership to Hungary and the need for a joint presentation of space activities pursued at BME. The selection of the date of the event pays tribute to the successful deployment to orbit and mission of the first Hungarian satellite, the Masat-1, which has been launched on February 13, 2012, so the conference is organized in every year in February. In 2016, the first European Space Generation Workshop of Space Generation Advisory Council has been organized as a joint event of the H-SPACE 2016 conference.

The education session of the H-SPACE conference series has a special focus on secondary and tertiary education. Fig.1. was taken before the official opening of the H-SPACE 2016 conference.

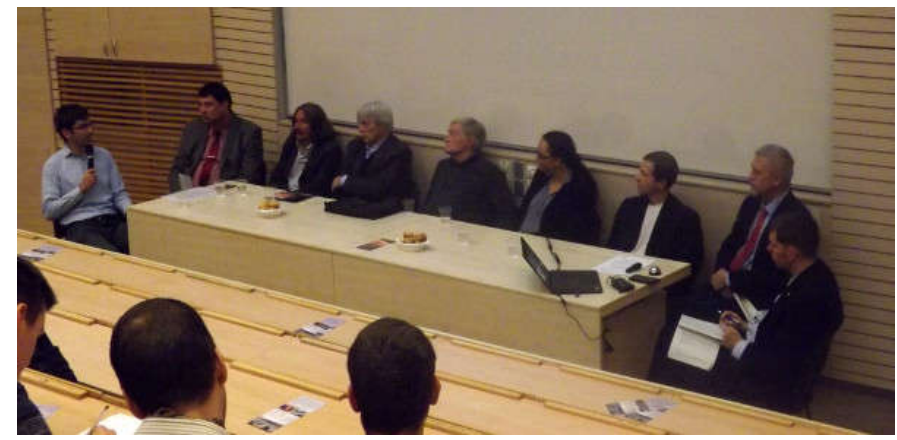

Fig. 2. Participants of the roundtable discusisons in 2016, organized by the Hungarian Astronautical Society with title: "Space engineering in Hungary: opportunities and challenges".

\section{B. Rountable discussion}

The Hungarian Astronautical Society (MANT) is the oldest Hungarian non-profit space association, founded in 1956. This society gathers Hungarian space researchers, users of space technology and everyone who is interested in the interdisciplinary and state-of-the-art uses and research of outer space. The aim of the association is to raise public awareness about space exploration and uses. It also provides opportunity for space enthusiasts to meet, exchange ideas and work together [11]. The society organizes several programs for the audience during the year including trips to space related institutes, student competitions and talks given by its members.

On October 21, 2016, the Hungarian Astronautical Society organized its annual Day of the Hungarian Space Research event. This is a half day event dedicated to the latest Hungarian and international research activities. In 2016, the event started with a 90-min-long workshop with Hungarian stakeholders about the space engineering: "Space engineering in Hungary: opportunities and challenges". The roundtable discussions with representatives of government, industry, universities, academia and space organization was followed by a direct questions and answers from the audience.

Participants of the roundtable discussions were the following (see Fig. 2.): Pál Bárczy (Admatis Ltd, HUNSPACE cluster), Dániel Bényei (Space Generation Advisory Council), Ákos Kereszturi (Research Centre for Astronomy and Earth Sciences, Hungarian Academy of Sciences), Kálmán Kovács

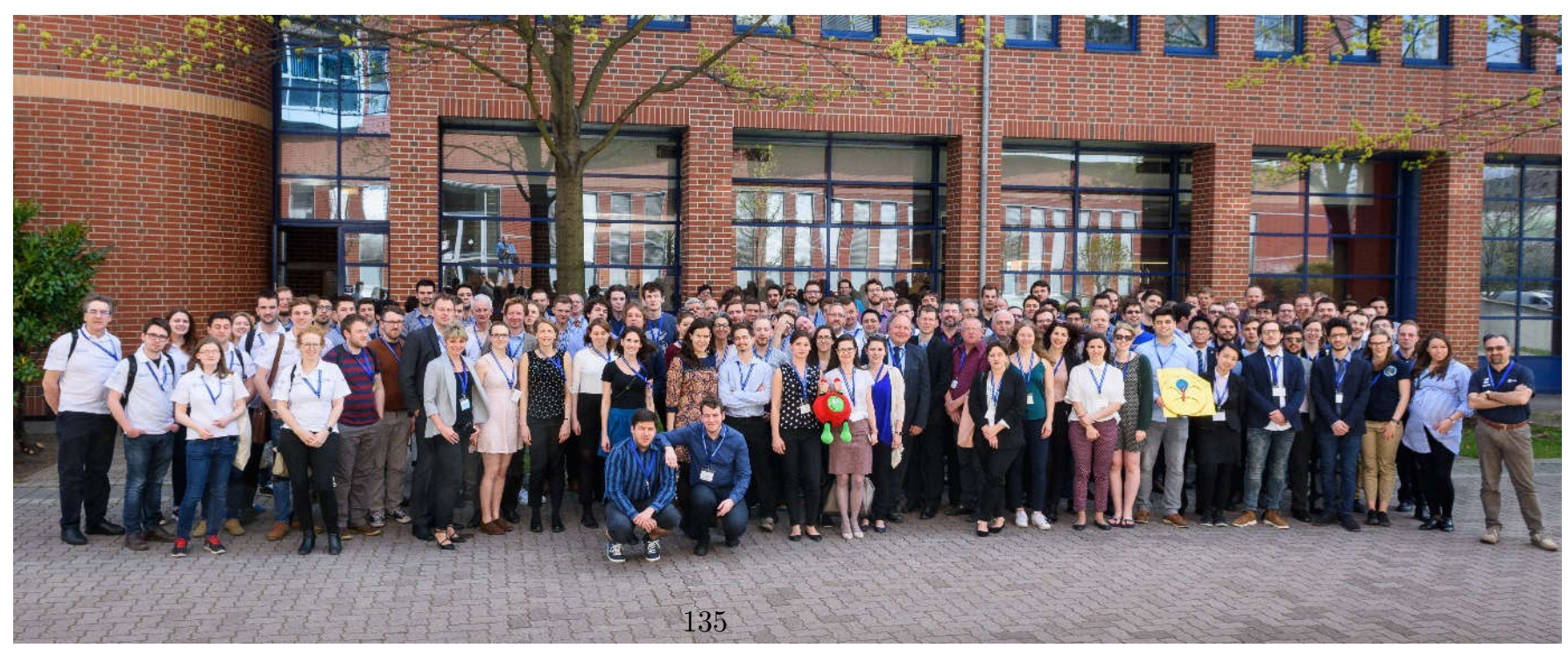

Fig. 3. Group photo of the participants of the $2^{\text {nd }}$ Symposium on Space Educational Activities in 2018 which was hosted by Budapest University of Technology and Economics and the Hungarian Astronautical Society in 2018 in Budapest, Hungary. 
(Budapest University of Technology and Economics), János Lichtenberger (Eötvös Loránd University), Ervin Rácz (Óbuda University), János Solymosi (BHE Bonn Hungary, HATP cluster), Fruzsina Tari (Hungarian Space Office), László Bacsárdi (Hungarian Astronautical Society).

Following the roundtable discussions, BME and MANT started to provide more space for tertiary education activities in their international H-SPACE conference series. In early 2017 , they decided to submit a proposal for hosting ESA's $2^{\text {nd }}$ Symposium on Space Educational Activities. MANT decided to continue the discussions of the roundtable discussions during its annual Space Academy series either in 2017 or in 2018.

\section{SSEA 2018}

In April 2018, BME and MANT organized the $2^{\text {nd }}$ Symposium on Space Educational Activities [12]. It followed the first symposium held in Padova, Italy in 2015, and continued to be an excellent forum for university students, professors and professionals from all over Europe to present and discuss their educational space-related projects and programs. We had a keynote presentation, six plenary lectures including an astronaut talk, more than 80 oral and poster presentations. Besides providing an opportunity for dissemination of information about educational and research activities, the symposium allowed sharing experience among students and young professionals from different countries and networking with international researchers. The symposium was held on April 11-13, 2018 at the premises of BME. All of our participants were invited to the Welcome reception on Wednesday in Trófea restaurant, a special Yuri's night party on Thursday in the Schönherz Dormitory and a Gala dinner on Friday evening with a 3-hour-long cruise on River Danube on board of the Európa ship. The symposium was organized by BME EIT in cooperation with MANT. The event was carried out under the supervision of European Space Agency's Education Office. We had 206 registered participants from 23 countries including 111 university students, 41 young professional and 54 professional participants. Fig.3. shows a group photo of the participants.

After the symposium, several discussions have started in the country about the importance of the space oriented tertiary education. These discussions were formalized during the $4^{\text {th }}$ Hungarian Space Academy, which was organized in Aug 2018.

\section{Space Academy 2018}

MANT started to organize its annual Hungarian Space Camp series for secondary school students in 1994. [13] As the continuation of the successful series, MANT decided to organize an event for university students and young professionals in 2014. Following the success of the one day event, together with the Space Generation Advisory Council (SGAC), MANT organizes a four-day summer event in August for Hungarian university students and young professionals between 18 and 35 years, named MANT Space Academy [14]. Every Space Academy has a specific topic. During the program, the participants listen lectures about Hungarian space projects. They work in small groups to create a detailed proposal about the chosen topic by the end of the event. Based on the final proposal, which include the benefits of the projects for Hungary, the participants can form teams and start working on the project during the next academy year [15]. In 2018, the event was organized on Aug 2-5 in Gödöllö, Hungary, and the space education was in the main focus. The participants, as illustrated in Fig.4., were discussing about the different educational possibilities. One of their final recommendation was the urgent implementation need for a master course in space engineering. Following the Space Academy, MANT has established a permanent working group on tertiary space education. The members of the working group started to collect information about different Hungarian tertiary education initiatives and subject.

\section{E. Intializing the establisment of space engineering curriculum}

The education of technical and scientific fundamentals of space activity has been part of the curriculum for decades at various Faculties of BME. Selected topics include satellite positioning (BSc), Satellite geodesy (MSc), Global navigation satellite systems (MSc), Environment and remote sensing (MSc), Optical systems design (BSc), , Space dynamics (BSc/MSc), Special propulsion, rockets $(\mathrm{BSc})$, Aerodynamics and dynamics of hypersonic flight (MSc), Space technology theory and practice (BSc/MSc), Telecommunications, Antennas and propagation, Critical embedded systems, High fidelity systems, Embedded systems, Cyberphysical systems, Quantum communication and many more.

In 2019, BME initialized a process which will lead to the establishment of the space engineering MSc curriculum in the country. If the curriculum is established, every Hungarian university which has the necessary competences can start a space engineering program for their students. Currently, we plan a two-year Master course which will cover the most important aspects of space engineering. The curriculum will consist of 120 credits, from which 30 credits will assign to Diploma thesis. The remaining 90 credits will be distributed among different subjects. Calculating with 5 credits per subject, it will allow 18 subjects for the curriculum. However, if the average credits is only 4 credit per subject, the space engineering curriculum can have 22 subjects.

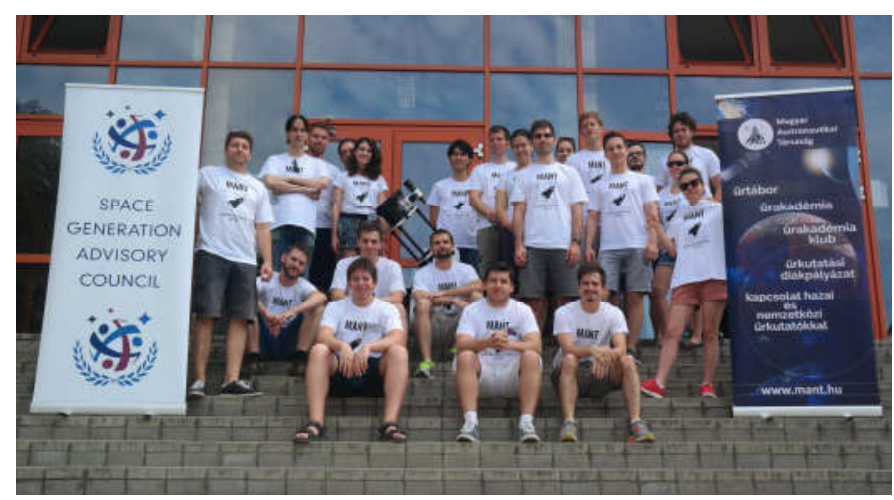

Fig. 4. Group photo of the participants of Hungarian Space Academy 2018. The event was organized on Aug 2-5, 2018 in Gödöllö, Hungary. The participants were university students and young professionals (age 18-35). The main discussion topic of the event was the tertiary space education. After the event, the Hungarian Astroautical Society has established its permanent Space Tertiary Education Working Group. 


\section{CONCLUSION}

Although Hungary is not a big country, there are more than 40 organizations (companies, research institutes, universities) which are part of the Hungarian space sector. Every Hungarian stakeholders agree in the importance of space oriented tertiary education. We believe that a space engineering master curriculum could utilities the Hungarian competences and offer continuous support to the workforce development in the space sector.

\section{ACKNOWLEDGMENT}

This paper was supported by the Higher Education Excellence Program of the Ministry of Human Capacities in the frame of the Artificial Intelligence Smart City (BME FIKPAISC) and Water sciences \& Disaster Prevention (BME FIKPVÍZ) research areas of BME.

\section{REFERENCES}

[1] Hungarian Space Directory, Budapest: TIT, 2016

[2] K. Kovács, "Space Activity of BME", Budapest: Hungarian Astronautical Society, 2017.

[3] K. Kovács, "Research-based education at BME" InProc. of the 2nd Symposium on Space Educational Activities, SSEA-2018-5 [SSEA 2018, April 11-13, 2018, Budapest, Hungary]

[4] Website of the BME EIT, http://eit.bme.hu (Last visited: Aug 12, 2019)

[5] K. Kovács (ed), Proceedings of 1st International Conference on Research, Technology and Education of Space, Budapest: 2015 [HSPACE 2015, Feb 13, 2015, Budapest, Hungary

[6] L. Bacsárdi, K. Kovács (eds), Proceedings of 2nd International Conference on Research, Technology and Education of Space,
Budapest: Hungarian Astronautical Society, 2016 [H-SPACE 2016, Feb 25-26, 2016, Budapest, Hungary

[7] L. Bacsárdi, K. Kovács (eds), Proceedings of 3rd International Conference on Research, Technology and Education of Space, Budapest: Hungarian Astronautical Society, 2017 [H-SPACE 2017, Feb 9-10, 2017, Budapest, Hungary

[8] L. Bacsárdi, K. Kovács (eds), Proceedings of 4th International Conference on Research, Technology and Education of Space, Budapest: Hungarian Astronautical Society, 2018 [H-SPACE 2018, Feb 15-16, 2018, Budapest, Hungary]

[9] L. Bacsárdi, K. Kovács, "Featured papers of the H-SPACE 2018 conference", INFOCOMMUNICATIONS JOURNAL, Vol X No 3., pp. 1, Sep 2018

[10] L. Bacsárdi, K. Kovács (eds), Proceedings of 5th International Conference on Research, Technology and Education of Space, Budapest: Hungarian Astronautical Society, 2019 [H-SPACE 2019, Feb 27-28, 2019, Budapest, Hungary]

[11] Website of the Hungarian Astronautical Socity, http://www.mant.hu (Last visited: Aug 12, 2019)

[12] L. Bacsárdi (ed), Proceedings of the 2nd Symposium on Space Educational Activities. Hungarian Astronautical Society 2018. [SSEA 2018, April 11-13, 2018, Budapest, Hungary]

[13] L. Bacsárdi, D. Milánkovich, "One Week Space - Lessons Learned from 25 Annual Hungarian Space Camps", In: Proc. of 69th International Astronautical Congress, 2018 Paper: IAC-18,E1,6,6,x45764 [IAC 2018, October 1-5, Bremen, Germany]

[14] D. Milánkovich, L. Bacsárdi, "Inspiring the lifelong learning of the Generation $Y$ - the space perspective", InProc. of XXII. Multimedia in Education Conference, pp.13-16, 2016 [Jun 3-4, 2016, Keszthely, Hungary]

[15] D. Milánkovich, I. Arnócz, L. Bacsárdi, "A strategy to support new careers in space sector", InProc. of the 2nd Symposium on Space Educational Activities, SSEA-2018-111 [SSEA 2018, April 11-13, 2018, Budapest, Hungary] 